\title{
THE APPLICATION OF A BALANCED SCORECARD IN SME: A CASE STUDY OF MILANZO KIDS
}

\author{
ASIH WULAN SARI* \\ NURVILAELI ALFIANY \\ AZALIA NOVIA HESTI \\ ALFI ZIADATUN NISA \\ IPB University \\ *asih_sari@apps.ipb.ac.id
}

\begin{abstract}
The processing industry is one of the non-agricultural SME sectors that ranks at the top in the national economy, of which there are $23 \%$ of players in the processing industry (BPS, 2016). According to a survey by the Ministry of Cooperatives and SMEs, during the Covid-19 Pandemic, the convection sector SMEs were the most affected sector with $78 \%$ of respondents claiming to have experienced a decrease in revenue and even had to close their businesses. Milanzo Kids is one of the convection SMEs that was established in 2013, engaged in the manufacture of children's t-shirts made of cotton and located in Jakarta, Indonesia. In 2020, Milanzo Kids experienced a decrease in revenue and profit from the previous year due to the Covid-19 pandemic. The objective of this study is to design a business development strategy using the balanced scorecard method. This research is a type of quantitative research. The data of this study were obtained from primary data through direct interviews and secondary data obtained from financial reports, journals, and books. The data processing method uses a balanced scorecard. The results of this study indicated that the total turnover per year and the number of products returned per year have the highest performance, namely the final score of 0.13 and the lowest performance indicator is the type of product produced with a final score of 0.03 .
\end{abstract}

Keywords: balanced scorecard, convection, covid-19, SMEs, strategic management

\section{INTRODUCTION}

During the covid-19 pandemic, many business sectors have been affected. With the Government's policies related to the pandemic, many activities have been hampered, especially buying and selling activities carried out by SMEs (Small and Medium Enterprises). In fact, the role of SMEs in Indonesia is very important because the many existing SMEs have improved the economy of the community and contributed to the per capita income of the Indonesian state. However, currently many SMEs are experiencing a decline in sales turnover and must compete with other SMEs that are able to survive in the midst of a pandemic and even the emergence of new SMEs because they are able to adapt to current conditions.

Based on the results of the 2016 BPS Economic Census, it is known that the number of nonagricultural SMEs is $26,263,649$ units with non-agricultural SMEs whose number of business actors ranks in the top three in the national economy, namely the processing industry business sector. In the manufacturing (manufacturing) industry category, there are around 3.4 million SMEs, the majority of whom are engaged in industry, one of which is textiles and convection with $14.4 \%$ of the industry (BPS, 2016). According to the Ministry of Cooperatives and SMEs, during the Covid-19 Pandemic, SMEs in the convection sector was the most affected sector with $78 \%$ of respondents claiming to experience a decline in income and even having to close their business with the largest category being a decline of more than $20 \%(67,5 \%)$. Although the majority of respondents do marketing online and offline $(63.40 \%)$, this still 
cannot improve existing business activities, due to the overall effect of the pandemic and resulting in a decline in consumer purchasing power.

SME leaders must be able to face the challenges of this pandemic with uncertainty whose impact may be greater than previous environmental conditions. There are various ways that can be done so that their business sector can still survive and not experience a drastic decline that will cause the business to go out of business. One way is to fix and improve performance in it with the method of measuring the performance of these SMEs in the form of innovative strategies. With the condition that the indicators of each strategy must be related to the indicators of other strategies. So that this strategy can be a solution to the problems faced by SMEs because the strategy map states the relationship between each strategic indicator perspective and other strategic indicator perspectives. In addition, the causal relationship is also described in the strategy map, so that it can be used as material for analysis for the development of SMEs (Sari et al., 2021).

Performance measurement is one of the most important factors for business organizations. Performance measurement methods are used to monitor the development of organizations and companies in order to maintain their competitiveness (Panudju et al., 2016). Performance measurement is used by comparing the performance of an SME (Small and Medium Enterprises) from the past period, the current period and the future period. From the results of the performance comparison, we can find out that the performance of SMEs is increasing or decreasing. Performance measurement so far is generally done traditionally, which only focuses on the financial aspect. Whereas in measuring the performance of a company can not only see from the financial side, but also non-financial (Utama \& Hariadi, 2013)

Seeing the progress of information technology and the development of management science, performance measurement in the traditional way can no longer be used because it will have many weaknesses and limitations from the results obtained. Therefore, Robert S. Kaplan (Professor of Accounting at Harvard Business School) and David P. Norton (President of Renaissance Solutions, Inc.) were compelled to design a more precise performance measurement system called the "Balanced Scorecard". Where this measurement system provides the strategic goals of the organization into a performance in interconnected SMEs. This Balanced Scorecard not only pays attention to financial performance, but also non-financial performance that will be appropriate to measure performance in a company or SMEs. Performance measurement based on the Balanced Scorecard can not only be applied to large companies, but also SMEs can take advantage of the BSC to improve internal business performance as well as as a tool in developing future business (Faizaty et al., 2019).

The application of the Balanced Scorecard method in SMEs will be able to measure how a business or business produces current values while considering future interests. Therefore, the Balanced Scorecard becomes a performance measurement that includes all aspects. The Balanced Scorecard is the right method for measuring performance, both from financial and non-financial aspects. The Balanced Scorecard concept is also suitable for use as a smart and innovative breakthrough that can help hospitals improve management performance. Non-financial information can increase confidence in the quality of management control processes.

Realizing the importance of implementing the Balanced Scorecard concept which is very effective and suitable for the management needs of a Milanzo Kids SME business, we tried to examine the possibility of implementing the Balanced Scorecard in the SME. Milanzo Kids is a business that sells boys' shirts. Milanzo Kids is currently experiencing an impact due to the covid-19 pandemic, where sales have decreased so that turnover has also decreased. The lack of utilizing technology also makes Milanzo Kids a little difficult to attract buying traction from potential buyers. The goal is to make the implementation of the Balanced Scorecard expected to help Milanzo Kids to be more developed by knowing and analyzing 
information for the Balanced Scorecard from previous years, then planning what strategies can increase these SMEs to compete with other SMEs that sell similar products to Milanzo Kids.

Milanzo Kids is one of the businesses that sells boys shirts. In 2020, Milanzo Kids SME experienced a decrease in revenue and profit from the previous year due to the Covid-19 pandemic, where sales so that turnover also decreased, the lack of utilizing technology also made Milanzo Kids a little difficult to attract potential buyers. Given the importance of implementing the Balanced Scorecard concept which is very effective and suitable for the management needs of an SME Milanzo Kids, we tried the possibility of implementing the Balanced Scorecard in the UKM. This research aims to design a business development strategy using the balanced scorecard method. Implementing the Balanced Scorecard is expected to help SMEs Milanzo Kids to be more developed by knowing and analyzing Balanced Scorecard information from previous years, then planning what strategies can increase these SMEs to compete with other SMEs that sell similar products with Milanzo Kids. So that the formulation of the problem in this research is 1) Is there any alignment between the vision, mission, strategic goals, and key performance indicators in Milanzo Kids 2) Is there a causal relationship from several perspectives on the Milanzo Kids strategy map 3) How is the balanced scorecard from Milanzo Kids.

In an organization or company, vision and mission are one of the important elements that can be the basis for the establishment of an organization. A vision is a statement that answers the basic question "What does the organization or company want to become?". A clear vision provides the foundation for developing a comprehensive mission statement (David \& David, 2017). A vision should be short, preferably one sentence but meaningful and present the organization or company.

After the vision is created, the mission can be formulated. The mission is the foundation for priorities, strategies, plans and work assignments. A mission must answer the question "What is our business?" which is a difficult question and the correct answer is usually not clear. The answer to this question is the strategist's first responsibility. An organization or company must pay attention to what mission the organization will carry on and allow the organization to run and set its goals.

According to (David \& David, 2017) goals are defined as specific results that an organization wants to achieve in relation to its mission. Strategic objectives are strategic goals of an organization that focus on general, board and long-term issues. Strategic objectives include such things as greater market share, faster on-time delivery than competitors, shorter design-to-market times than competitors, etc. Strategic objectives relate to results that show the company is strengthening its market position, competitive vitality, and future business prospects (Gamble, J et al., 2013).

In 1992, Robert S. Kaplan and David Norton began to introduce the Balanced Scorecard through a Harvard Business Review article. After the publication, several companies began to adopt the balanced scorecard. Balanced scorecard. The balanced scorecard began to expand into management tools to describe, communicate, and implement strategy (Kaplan, 2010). The balanced scorecard can be used to develop a business strategy from four perspectives, namely financial perspective, customer perspective, internal business process perspective, and learning and growth perspective. Here is the original structure of the Balanced Scorecard. 


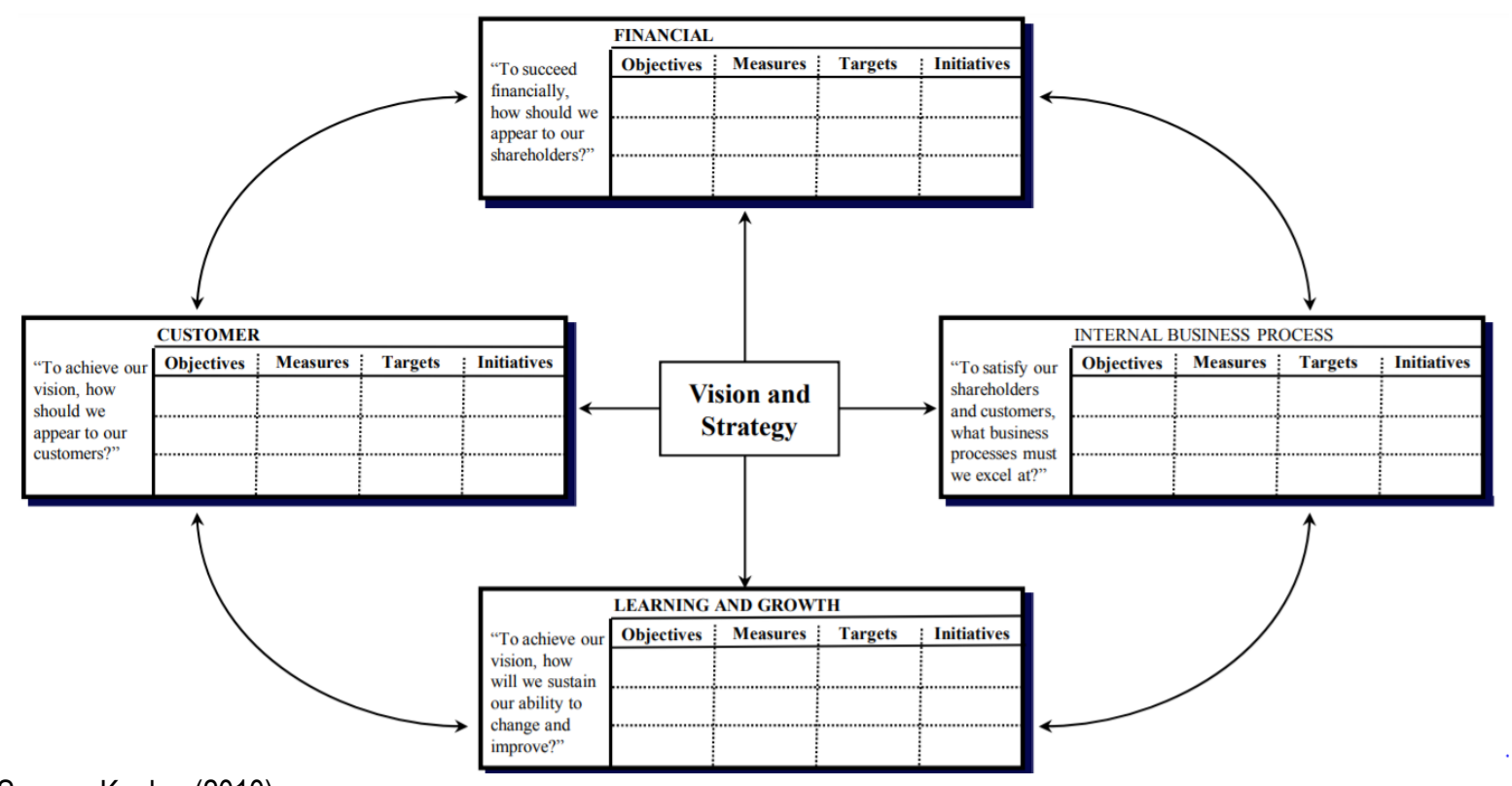

Source: Kaplan (2010)

Figure 1. Translating Vision and Strategy: Four Perspective

According to Figure 1, the organization's vision and strategy consist of four sustainable perspectives and are described with objectives, measures, targets and initiatives. Niven (2002) describes the balanced scorecard as a tool to carefully measure a company's strategy. The balanced scorecard is used by leaders to communicate to employees and stakeholders about the results performance drives by which the organization will achieve its mission and strategic goals.

The idea of a causal relationship between the objectives and measures of the balanced scorecard leads to the creation of a strategy map. Figure 2 shows the structure for the strategy map. In the project of creating a balanced scorecard, a strategy map is built first and then a matrix is selected for each objective.

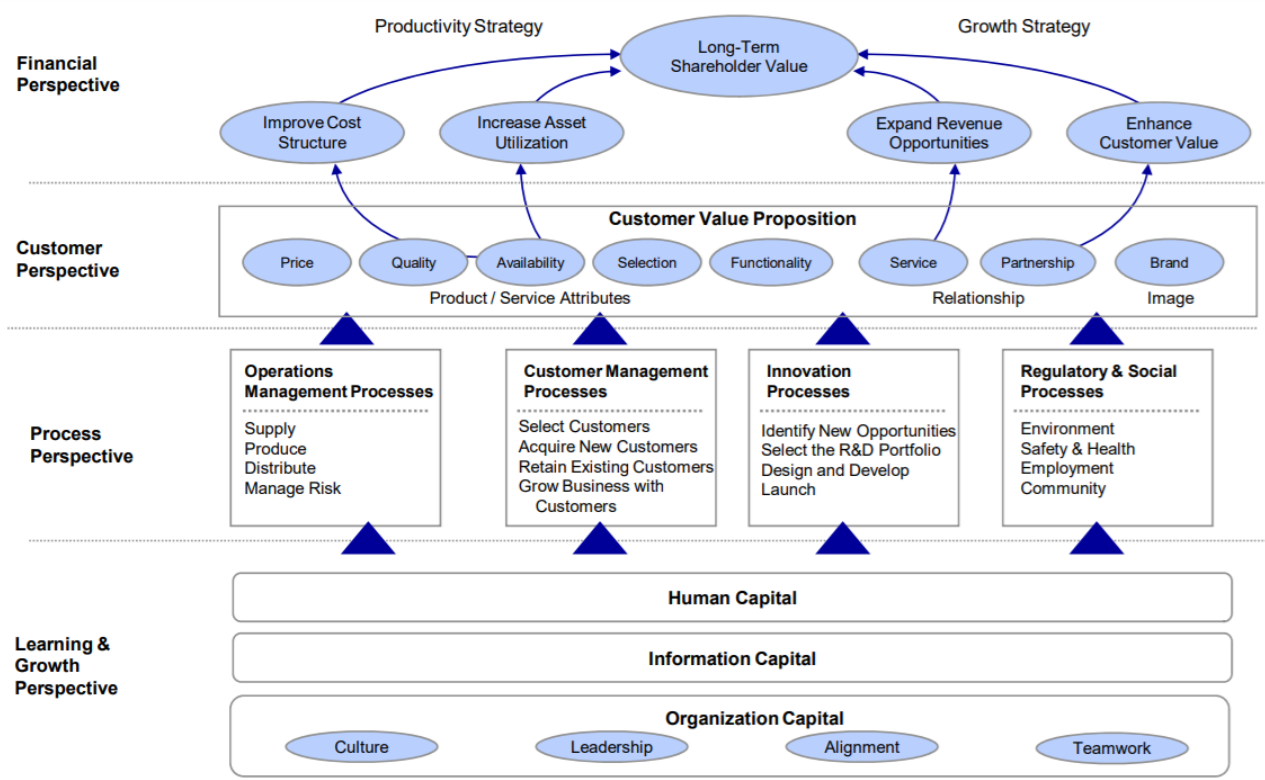

Source: Kaplan (2010)

Figure 2. Strategy Maps 
According to Figure 2, The financial perspective is the highest goal of a profit organization. The learning and growth perspective which consists of human capital, information capital and organization capital has a causal relationship with the internal business process perspective. The internal business process perspective which consists of operations management processes, customer management processes, innovation processes and regulatory \& social processes has a causal relationship with the customer perspective. The customer perspective seen from the customer value proposition has a causal relationship with the financial perspective which is the highest goal of a profit organization.

After compiling the strategy map, the next step in the balanced scorecard is compiling key performance indicators. Key Performance Indicators (KPI) are indicators that focus on aspects of organizational performance for the current and future success of the organization (Parmenter, 2015). There are seven characteristics of KPI obtained from Parmenter (2015) through the discussion, namely non-financial, timely, CEO focus, simple, team based, significant impact, and limited dark side. In addition, in preparing KPIs, the SMART-C principle can be used, which means specific, measurable, achievable, relevant, timely, and continuous improvement.

\section{METHOD}

To be able to achieve the research objectives described in the introduction, the research was carried out in the following stages.

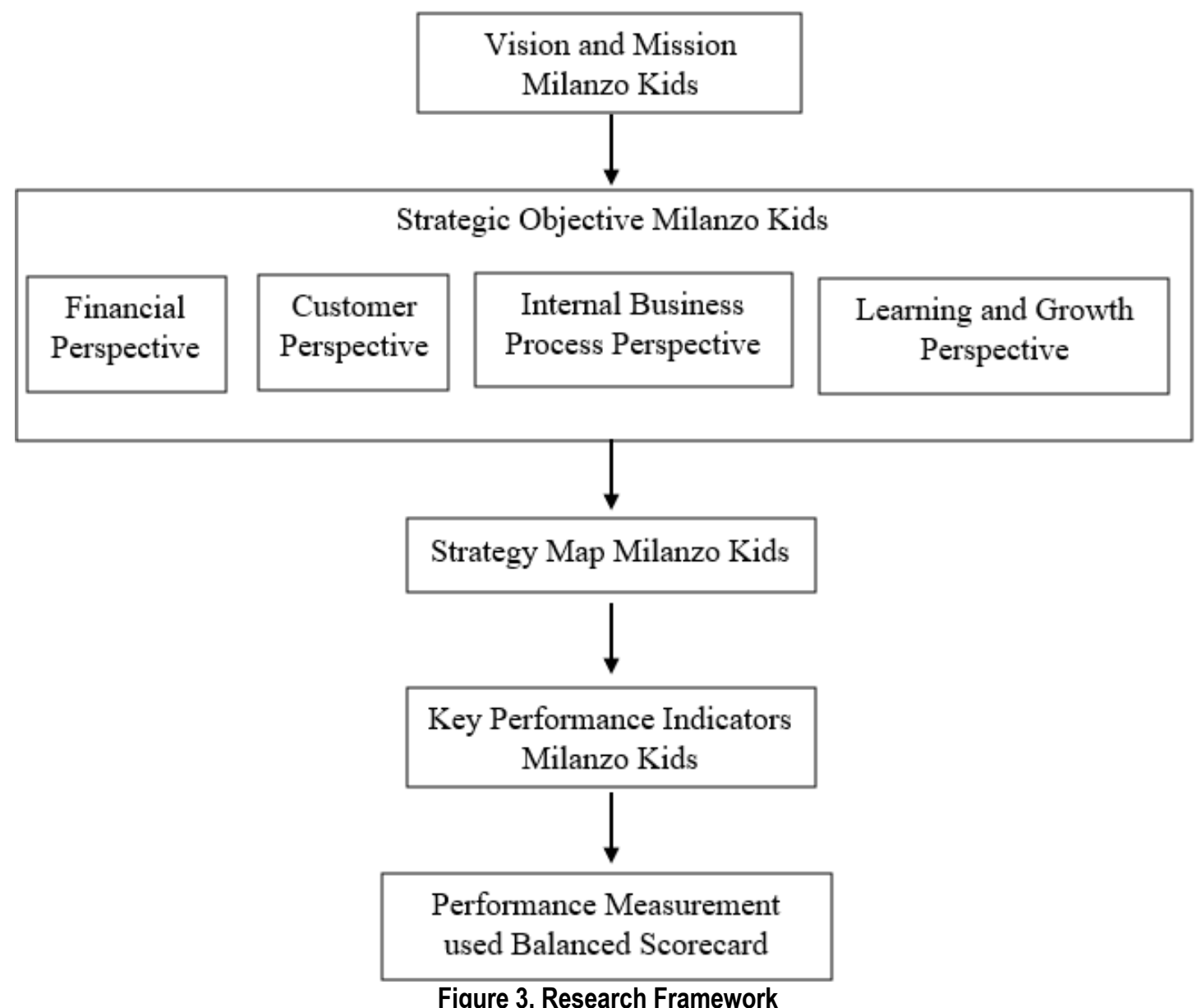

Referring to the diagram above, the research begins by developing a vision and mission that is in accordance with the Milanzo Kids. Next, to determine the strategic goals of Milanzo Kids by using four 
perspectives, namely financial, customer, internal business process, and learning and growth perspective. Analysis of the relationship between each strategic goal using a strategic map. Furthermore, from the existing strategic objectives, key performance indicators from Milanzo Kids were compiled. After that, analyze the performance measurement using the balanced scorecard based on the data that has been collected. Data collected through interviews with the milanzo kids owner and milanzo kid's production and finance reports. Performance measurement will determine which are the highest and lowest performances at Milanzo Kids from these four perspectives and whether they need to be improved or developed.

\section{RESULTS}

Milanzo kids is a wholesale SME that sells children's clothes from 1-12 years old. Milanzo Kids was founded in 2003 with an owner named Mr. Agusman. The price sold per dozen by Milanzo Kids ranges from IDR 600,000 - IDR 750,000. The store locations of Milanzo Kids are in Cipulir Market and Tanah Abang Market. Milanzo Kids has 93 employees consisting of Finance, Production, and Marketing. Figure 4 shows the organizational structure of Milanzo Kids. The organizational structure that has been made can be seen in Figure 4

\section{Organizational Structure of Milanzo Kids}

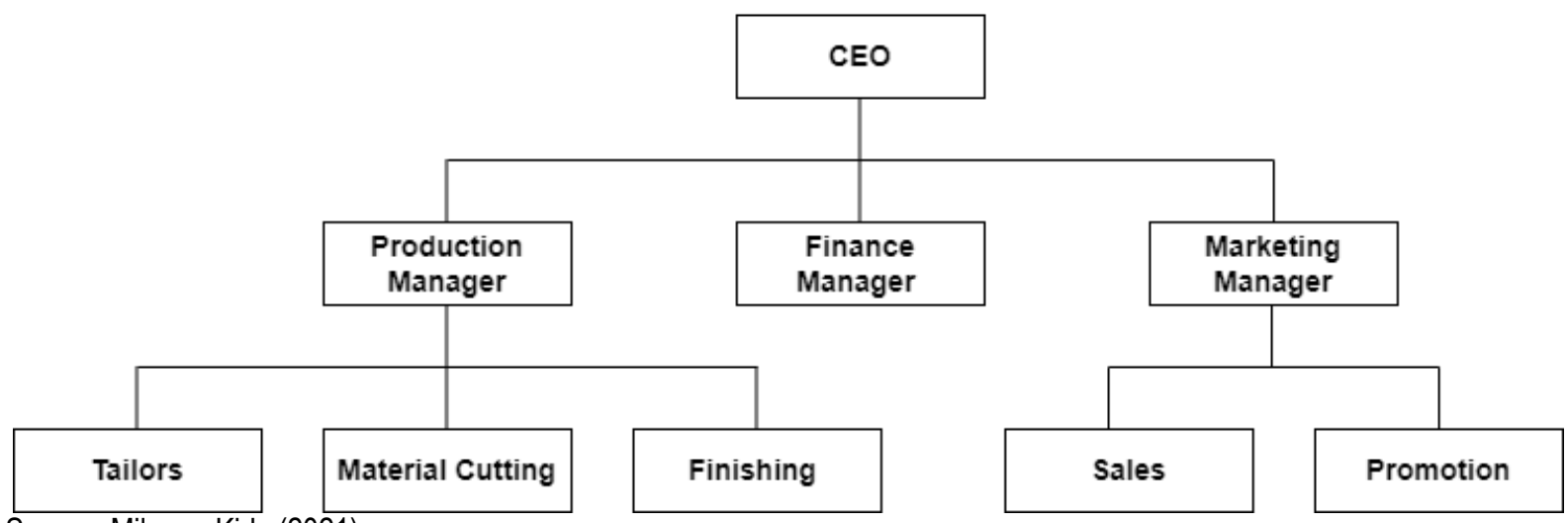

Source: Milanzo Kids (2021)

Figure 4. Organizational structure

According to figure 4 The organizational structure, Milanzo Kids has a total of 93 employees, including 1 person in the Finance division, 88 people in the Production division consisting of tailors, material cutting, and finishing sections, while 4 people in the Marketing division.

Based on four perspectives in making the balanced scorecard, the vision and mission of UKM Milanzo Kids are realized in several strategic goals. Vision and mission are made on a systematic map so that they can be seen easily. The strategic map that has been made can be seen in Figure 5 . 
Table 1. Vision and Mission

\begin{tabular}{|c|c|c|c|c|c|}
\hline Vision & Alignment & Mission & Alignment & & Goal \\
\hline \multirow{8}{*}{$\begin{array}{c}\text { The vision of Milanzo Kids is "To } \\
\text { become the no. } 1 \text { Convection SME } \\
\text { in DKI Jakarta with affordable price } \\
\text { and good quality and providing the } \\
\text { best service to consumers }\end{array}$} & & \multirow{2}{*}{$\begin{array}{l}\text { Maintain the quality of } \\
\text { raw materials and } \\
\text { production quality to } \\
\text { produce quality products }\end{array}$} & \multirow{2}{*}{$a, b$} & a & Raw material quality \\
\hline & & & & b & Production quality \\
\hline & & \multirow{2}{*}{$\begin{array}{l}\text { Providing the best } \\
\text { Service to Milanzo Kids } \\
\text { customers }\end{array}$} & \multirow{2}{*}{$c, f$} & $c$ & Service quality \\
\hline & & & & d & Affordable pnces \\
\hline & & \multirow{2}{*}{$\begin{array}{l}\text { Consistently produce } \\
\text { local products at } \\
\text { affordable prices }\end{array}$} & \multirow{2}{*}{ d } & e & Following market trends \\
\hline & & & & $f$ & Customer loyalty \\
\hline & & $\begin{array}{l}\text { Making quality local } \\
\text { products by following } \\
\text { current market trends }\end{array}$ & a,b.e & \multirow[b]{2}{*}{$g$} & \multirow{2}{*}{ Employee welfare } \\
\hline & & $\begin{array}{c}\text { Provide adequate trainmg } \\
\text { and incentives to } \\
\text { employees }\end{array}$ & G & & \\
\hline
\end{tabular}

Source: Milanzo Kids (2021)

According to table 1, the strategic goals of Milanzo Kids include quality of raw materials, quality of production, quality of service, affordable prices, following market trends, customer loyalty, and employee welfare.

After formulating goals with Milanzo Kids, the next step is to set strategic objectives. The strategic objectives are made in the systematic map in order to clearly see the causal relationship between the strategic objectives. The strategic map that has been made can be seen in Figure 5.

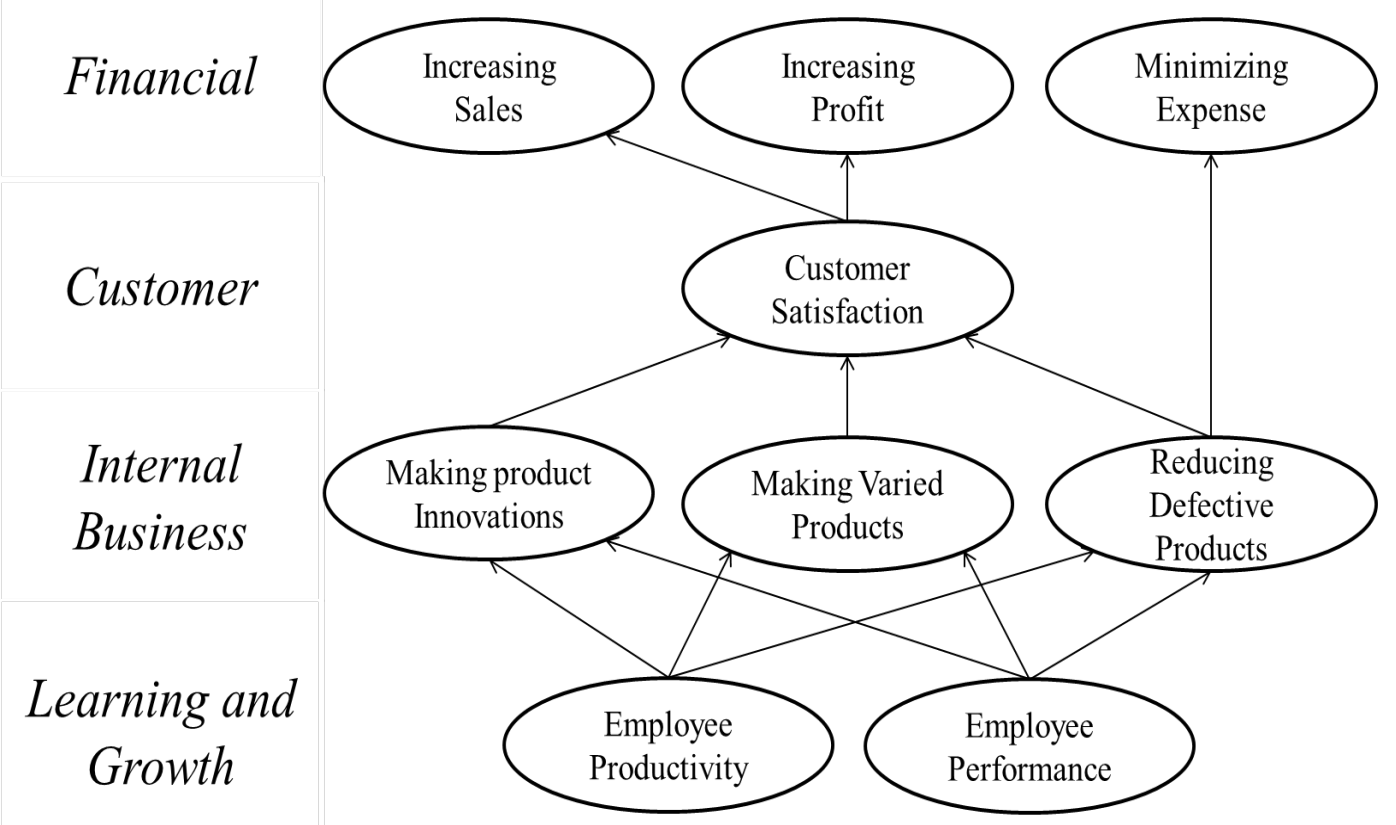

Source : Milanzo Kids (2021)

Figure 5. Strategic Map of Milanzo Kids

According to Figure 5, it can be seen that employee productivity and employee performance affect internal business processes with strategic objectives in the form of making product innovations, making varied products, and reducing defective products. All strategies objectives with the perspective of internal business processes that affect customer satisfaction. If customers are satisfied with Milanzo Kids products 
and services, this can affect sales and profits. So there is a relationship between customer satisfaction with increased sales and increased profits. In addition, there is a relationship between reducing defective products and minimizing costs because if the product has fewer defects, it will reduce the production costs of Milanzo Kids. Financial perspective is the highest strategy because Milanzo Kids is a type of profit organization.

After making strategic objectives, the next step is to evaluate performance by formulating key performance indicators (KPI) for each strategic objective. Each $\mathrm{KPI}$ is assigned a weight, the weighting is discussed with the CEO of Milanzo Kids. After that, the score of each KPI is calculated by calculating the comparison between the target and the realization. In addition, it is also necessary to formulate strategic initiatives, person in charge (PIC), and budget for each KPI. The Financial Perspective has 3 strategic objectives and $3 \mathrm{KPIs}$ that are aligned, namely total turnover, total profit, and total expense per year. Discussions and calculations related to the financial perspective can be seen in table 2 .

Table 2. Scorecard Financial Perspective Milanzo Kids

\begin{tabular}{|c|c|c|c|c|c|c|c|c|c|c|c|}
\hline Perspective & Weight & $\begin{array}{c}\text { Strategic } \\
\text { Objectives }\end{array}$ & KPI & Weight & $\begin{array}{c}\text { Target } \\
2020\end{array}$ & $\begin{array}{c}\text { Realization } \\
2020\end{array}$ & Score & $\begin{array}{l}\text { Total } \\
\text { Score }\end{array}$ & Strategic Initiatives & PIC & Budget \\
\hline \multirow[t]{3}{*}{ Financial } & 0.6 & $\begin{array}{l}\text { Increase } \\
\text { sales }\end{array}$ & $\begin{array}{l}\text { Total } \\
\text { turnover } \\
\text { per year } \\
\text { (IDR) }\end{array}$ & 0.2 & $12 \mathrm{~B}$ & $8 B$ & 0.67 & 0.13 & $\begin{array}{l}\text { Conduct product marketing } \\
\text { through social media and e- } \\
\text { commerce to expand market } \\
\text { share, Provide special } \\
\text { discount for some product }\end{array}$ & Marketing & $\begin{array}{l}\text { IDR } \\
50 \mathrm{M}\end{array}$ \\
\hline & & $\begin{array}{l}\text { Increase } \\
\text { profit }\end{array}$ & $\begin{array}{l}\text { Total profit } \\
\text { per year } \\
\text { (IDR) }\end{array}$ & 0.2 & $5 B$ & $3 B$ & 0.6 & 0.12 & $\begin{array}{l}\text { Looking for suppliers who } \\
\text { provide good quality and } \\
\text { cheaper prices, Minimize } \\
\text { expenses, Increase sales }\end{array}$ & CEO & IDR 5M \\
\hline & & $\begin{array}{l}\text { Minimize } \\
\text { expenses }\end{array}$ & $\begin{array}{l}\text { Total } \\
\text { expenses } \\
\text { per year } \\
\text { (IDR) }\end{array}$ & 0.2 & $3 B$ & $5 B$ & 0.6 & 0.12 & $\begin{array}{l}\text { Producing with an average } \\
\text { product sold every year so } \\
\text { that there is no excess } \\
\text { product, saving/minimizing } \\
\text { production cost (electricity and } \\
\text { materials) }\end{array}$ & Finance & 0 \\
\hline
\end{tabular}

Source : Proceed (2021)

According to table 2, the total turnover indicator has the best performance even though the realization did not reach the target. This decline in turnover was caused by the Covid-19 pandemic that hit Indonesia in March 2020. The total profit indicator also did not reach the target. The decline in profit was due to a decrease in turnover due to the Covid-19 pandemic. Meanwhile, the total expense indicator has increased because production has been carried out as much as possible for inventory. However, due to the Covid-19 pandemic, not many product stocks came out.

The Customer Perspective has 1 strategic objective and $1 \mathrm{KPI}$ that is aligned, namely the number of complaints. Discussions and calculations related to the Customer Perspective can be seen in table 3 .

Table 3. Scorecard Customer Perspective Milanzo Kids

\begin{tabular}{|c|c|c|c|c|c|c|c|c|c|c|c|}
\hline Perspective & Weight & $\begin{array}{c}\text { Strategic } \\
\text { Objectives }\end{array}$ & KPI & Weight & $\begin{array}{c}\text { Target } \\
2020\end{array}$ & $\begin{array}{c}\text { Realization } \\
2020\end{array}$ & Score & $\begin{array}{l}\text { Total } \\
\text { Score }\end{array}$ & Strategic Initiatives & PIC & Budget \\
\hline Customer & 0.1 & $\begin{array}{l}\text { Customer } \\
\text { satisfaction }\end{array}$ & $\begin{array}{l}\text { Number of } \\
\text { complaints } \\
\text { (person) }\end{array}$ & 0.1 & $\begin{array}{c}11 \\
\text { person }\end{array}$ & 20 person & 0.55 & 0.06 & $\begin{array}{l}\text { Making quality products with good } \\
\text { materials, competent tailors and } \\
\text { affordable prices and serving } \\
\text { customers with a friendly attitude and } \\
\text { providing additional facilities such as: } \\
\text { seats, consumption, and fans }\end{array}$ & Marketing & $\begin{array}{l}\text { IDR } \\
12 \mathrm{M}\end{array}$ \\
\hline
\end{tabular}

Source : Proceed (2021)

According to table 3 , the indicator Number of complaints exceeds the specified target. The reason is most of Milanzo Kids' customers are resellers. Meanwhile, during the Covid-19 Pandemic, people's purchasing power decreased, causing Milanzo Kids resellers to lose customers and complain to Milanzo Kids regarding the price they got to make it cheaper and to attract people's purchasing power again.

The Internal Business perspective has 3 strategic goals and $3 \mathrm{KPIs}$ that are aligned, namely the 
number of product innovations each year, the types of products produced per year and the number of product returns each year. Discussions and calculations related to the Internal Business perspective can be seen in table 4.

Table 4. Scorecard Internal Business Process Perspective Milanzo Kids

\begin{tabular}{|c|c|c|c|c|c|c|c|c|c|c|c|}
\hline Perspective & Weight & $\begin{array}{l}\text { Strategic } \\
\text { Objectives }\end{array}$ & KPI & Weight & $\begin{array}{l}\text { Target } \\
2020\end{array}$ & $\begin{array}{l}\text { Realization } \\
\quad 2020\end{array}$ & Score & $\begin{array}{l}\text { Total } \\
\text { Scor } \\
\text { e }\end{array}$ & Strategic Initiatives & PIC & Budget \\
\hline \multirow[t]{3}{*}{$\begin{array}{l}\text { Internal } \\
\text { Business }\end{array}$} & 0.2 & $\begin{array}{l}\text { Make } \\
\text { product } \\
\text { innovation }\end{array}$ & $\begin{array}{l}\text { Number of } \\
\text { product } \\
\text { innovations } \\
\text { each year }\end{array}$ & 0.2 & 4 & 4 & 1 & 0.05 & $\begin{array}{l}\text { Always look at market trends } \\
\text { that are in demand by the } \\
\text { public (up to date). }\end{array}$ & CEO & IDR $5 \mathrm{M}$ \\
\hline & & $\begin{array}{l}\text { Make a } \\
\text { variety of } \\
\text { products }\end{array}$ & $\begin{array}{l}\text { Types of } \\
\text { product } \\
\text { produced } \\
\text { per year }\end{array}$ & 0.2 & 22 & 15 & 0.68 & 0.03 & $\begin{array}{l}\text { Provides a variety of } \\
\text { models, motifs, and sizes }\end{array}$ & $\begin{array}{l}\text { Prod } \\
\text { uctio } \\
n\end{array}$ & 0 \\
\hline & & $\begin{array}{l}\text { Reduce } \\
\text { defective } \\
\text { products }\end{array}$ & $\begin{array}{l}\text { Number of } \\
\text { product } \\
\text { return each } \\
\text { year } \\
\text { (dozen) }\end{array}$ & 0.2 & $\begin{array}{c}200 \\
\text { dozen }\end{array}$ & 150 dozen & 1.33 & 0.13 & $\begin{array}{c}\text { Buy a quality materials, } \\
\text { Supervise the production } \\
\text { process }\end{array}$ & CEO & IDR 4B \\
\hline
\end{tabular}

Source : Proceed (2021)

According to table 4, data on the number of product innovations produced per year comes from the number of products with new designs produced annually by Milanzo Kids. As well as data on the types of new products produced per year from the types of products produced, such as the manufacture of shirts, pants and so on. In the KPI to reduce defective products, it is obtained from data on the number of products that are returned each year due to defects or damage. The Learning and Growth perspective has 2 strategic goals and $2 \mathrm{KPIs}$ that are aligned, namely the number of products produced per year and the number of employee training per year. Discussions and calculations related to Learning and Growth can be seen in table 5 .

Table 5. Scorecard Learning and Growth Perspective Milanzo Kids

\begin{tabular}{|c|c|c|c|c|c|c|c|c|c|c|c|}
\hline Perspective & Weight & $\begin{array}{l}\text { Strategic } \\
\text { Objectives }\end{array}$ & KPI & Weight & $\begin{array}{c}\text { Target } \\
2020\end{array}$ & $\begin{array}{c}\text { Realization } \\
2020\end{array}$ & Score & $\begin{array}{l}\text { Total } \\
\text { Score }\end{array}$ & Strategic Initiatives & PIC & Budget \\
\hline \multirow[t]{2}{*}{$\begin{array}{l}\text { Learning and } \\
\text { Growth }\end{array}$} & \multirow[t]{2}{*}{0.1} & $\begin{array}{l}\text { Increased } \\
\text { employee } \\
\text { productivity }\end{array}$ & $\begin{array}{l}\text { Number of } \\
\text { products } \\
\text { produced per } \\
\text { year(dozen) }\end{array}$ & 0.1 & $\begin{array}{l}25000 \\
\text { dozen }\end{array}$ & $\begin{array}{l}25000 \\
\text { dozen }\end{array}$ & 1 & 0.05 & $\begin{array}{l}\text { Give bonuses to high- } \\
\text { performing employees } \\
\text { and create a comfortable } \\
\text { workplace atmosphere }\end{array}$ & CEO & $\begin{array}{l}\text { IDR } \\
150 \mathrm{M}\end{array}$ \\
\hline & & $\begin{array}{l}\text { Improved } \\
\text { employee } \\
\text { performance }\end{array}$ & $\begin{array}{l}\text { Number of } \\
\text { employee } \\
\text { training per } \\
\text { year }\end{array}$ & 0.1 & 2 & 2 & 1 & 0.05 & Conduct job training & CEO & $\begin{array}{l}\text { IDR } \\
50 M\end{array}$ \\
\hline
\end{tabular}

Source : Proceed (2021)

According to table 5, in KPI employee work productivity, seen from how many items can be produced by employees each year. Meanwhile, in KPI the increase in employee performance is measured by using the number of employee training carried out each year.

Based on the performance evaluation using the balanced scorecard, it can be seen that aspects that need to be improved, one of which is the type of product produced per year because it is still at the lowest score of only 0.03 . In addition, from the four perspectives used, the financial perspective has the best performance because it gets the highest score even though the realization achieved does not meet the targets that have been made. The realization that did not meet the target from a financial perspective was one of the causes due to the Covid-19 pandemic, so the Milanzo Kids Store was forced to close due to policies set by the government. Meanwhile, the learning and growth perspective has low performance and improvements must be made so that the performance is even better, even though the realizations 
obtained meet the targets that have been made. Performance assessment using the balanced scorecard, of course, still needs to be evaluated continuously and made improvements to suit current developments.

\section{CONCLUSION}

The implementation of the balanced scorecard on Milanzo Kids used four perspectives, namely financial perspective, customer perspective, internal business processes perspective, and learning and growth perspective. The result of this research are:

1. In Milanzo Kids' vision, mission, goals, strategic objectives and key performance indicators, there is an alignment with the four perspectives of the balanced scorecard,

2. In the Milanzo Kids map strategy, there is a causal relationship between the learning growth perspective and the internal business perspective, the customer perspective and the internal business perspective, and the financial perspective with the customer and the internal business perspective,

3. According to the scorecard of key performance indicators, the total turnover per year and the number of products returned per year has the highest performance, namely the final score of 0.13 . While, the lowest performance indicator is the type of product produced with a final score of 0.03 .

It is necessary to continuously improve the size of the strategy so that Milanzo Kids' performance can be re-evaluated and in accordance with current developments. Performance assessment using the balanced scorecard produces a perspective that performance is good or not for improvement and development as well as developing strategies that can be applied so that targets can be achieved. Suggestions for further research, in giving the weighted balanced scorecard should be discussed again so that the results provided are more accurate.

\section{REFERENCES}

BPS. (2016). Sensus Ekonomi 2016. http://se2016.bps.go.id

David, F. R., \& David, F. R. (2017). Strategic Management Concept and Cases. In Strategic Management (Sixteenth). Prentice Hall.

Faizaty, N. E., Trisnowati, Y., Anthony, A., \& Sari, E. D. A. (2019). Perancangan Instrumen Pengukuran Kinerja Usaha UKM Kalem Coffe Dengan Pendekatan Balanced Scorecard. Jurnal Manajerial, 6(1), $9-16$.

Gamble, J, E., Peteraf, M, A., \& Thompson Jnr, A, A. (2013). Essentials for strategic management: The quest for competitive advantage. McGraw-Hill Education.

Kaplan, R. S. (2010). Conceptual Foundations of the Balanced Scorecard. In Handbooks of Management Accounting Research.

Kaplan, R. S. \& David, P. N. (1996). The Balanced Scorecard: Translating Strategy into Action.

Niven, P. R. (2002). Balanced Scorecard Step-by-Step. John Wiley \& Sons, Inc.

Panudju, A. T., Asfar, A. H., \& Fauziah, F. (2016). Pengukuran Kinrja Perusahaan Menggunakan Metode Balanced Scorecard (BSC) Dengan Pembobotan Analytical Hierarchy Process (AHP) Di PT. ABC, TBK. Integrasi Sistem Industri, 3(December), 55-65.

Parmenter, D. (2015). Key Performance Indicators: Developing, Implementing, and Using Winning KPIs. John Wiley \& Sons, Inc.

Sari, I. A., Wahyuhastuti, N., \& Yunus, M. (2021). MSME development strategy in central java province through a swot balanced scorecard analysis approach. Monex: Journal of Accounting Research, 10, 184-193.

Utama, N. A., \& Hariadi, B. (2013). Analisis Pengukuran Kinerja Rumah Sakit dengan Pendekatan Balanced Scorecard (Studi Kasus Pada RSUD Prof. Dr. Soekandar Mojosari). Jurnal IImiah Mahasiswa FEB Universitas Brawijaya, 1(2). 